\title{
MATHEMATICAL MODELS FOR EVALUATING THE INFLUENCE OF DEGRADATION ON THE TENSILE AND FLEXURAL PROPERTIES OF PALM KERNEL SHELL ASH/EPOXY COMPOSITES
}

\author{
MATEMATIČNI MODELI ZA OVREDNOTENJE VPLIVA \\ DEGRADACIJE NA NATEZNE IN UPOGIBNE LASTNOSTI EPOKSI \\ KOMPOZITOV Z DODATKOM PEPELA IZ LUPIN PALMINIH PEŠK \\ KOT OJAČITVENE FAZE
}

\author{
Isiaka Oluwole Oladele ${ }^{1}$, Adeolu Adesoji Adediran ${ }^{2 *}$, \\ Akeem Damilola Akinwekomi ${ }^{1}$, Peace Pamilerin Adara ${ }^{1}$ \\ ${ }^{1}$ Department of Metallurgical and Materials Engineering, Federal University of Technology, PMB 704, Akure, Ondo State, Nigeria \\ ${ }^{2}$ Department of Mechanical Engineering, Landmark University, Omu-Aran, PMB 1001, Kwara State, Nigeria \\ Prejem rokopisa - received: 2019-01-22; sprejem za objavo - accepted for publication: 2019-05-17
}

doi: $10.17222 /$ mit.2019.021

\begin{abstract}
This work developed mathematical models for predicting the influence of degradation on the mechanical properties of palm kernel shell ash (PKSA) reinforced epoxy composites. The composites after production were divided into three parts, one part was used as the control samples while the other two parts were buried in soil and water, respectively for $90 \mathrm{~d}$ after which experimental tests were carried out based on the ASTM standards. The experimental data from the tensile and flexural properties were analyzed and modeled using a multiple regression analysis to generate higher-order polynomial equations solved to obtain the predicted values. Comparison and validation of the models was carried out through the use of data analysis (T-test and Perron-Frobenious theorem). The result gotten revealed that the tensile properties could be accurately predicted by the developed models at reinforcement of ( $\leq 8 w / \%$ and $\geq 16 w / \%$ for normal), ( $\leq 8 w / \%$ for soil) and ( $\leq 8 w / \%$ for water) while flexural strength was accurately predicted at reinforcement of ( $\leq 6 w / \%$ and $\geq 18 w / \%$ for normal), $(\leq 6 w / \%$ and $\geq 14 w / \%$ for soil) and ( $\geq 1 \mathrm{w} / \%$ for water).

Keywords: tensile, flexural properties, degradation, composite, models, regression analysis
\end{abstract}

V članku avtorji opisujejo razvoj matematičnih modelov za napoved vpliva degradacije na mehanske lastnosti epoksi kompozita, ojačanega s pepelom iz lupin palminih pešk (PKSA). Po izdelavi kompozita so le-tega razdelili na tri dele, en del so uporabili kot kontrolni vzorec, medtem ko so enega od ostalih dveh vzorcev zakopali v zemljo in drugega potopili v vodo za 90 dni. Sledilo je testiranje tako izpostavljenih kompozitov v skladu z ASTM standardi. Eksperimentalno dobljene rezultate natezne in upogibne trdnosti so analizirali in modelirali z uporabo multiple regresijske analize za generiranje polinomskih enačb višjega reda in z njihovo pomočjo napovedali analitične vrednosti. Izvedli so validacijo in primerjavo modelov z uporabo podatkovnih analiz (T-test in Perron-Frobeniousov teorem). Dobljeni rezultati analiz so pokazali, da lahko z razvitimi modeli natančno napovemo natezne lastnosti kompozitov pri vsebnostih ojačitvene faze $\leq 8$ mas. $\%$ in $\geq 16$ mas. $\%$ za kontrolne, $\leq 8$ mas. $\%$ za zakopane v zemljo in $\leq 8$ mas.\% za potopljene v vodo, medtem ko so lahko upogibno trdnost natančno napovedali za kompozite $\mathrm{z}$ vsebnostjo ojačitvene faze $\leq 6$ mas. $\%$ in $\geq 18$ mas. $\%$ za kontrolne, $\leq 6$ mas. $\%$ in $\geq 14$ mas. $\%$ za zakopane v zemljo in $\geq 1$ mas. $\%$ za potopljene v vodo.

Ključne besede: natezne in upogibne mehanske lastnosti, degradacija, kompozit, modeli, regresijska analiza

\section{INTRODUCTION}

The interest in the development of advanced materials for applications in the aerospace, automobile and construction industries has been one of the cogent and propelling factors driving the development of polymerbased composites, especially the ones whose reinforcements are naturally available and environmentally friendly. Green composites, which are defined as biopolymers or bio-derived polymers reinforced with natural fibers, have potential uses in the automotive and construction sectors. Composites are materials that

*Corresponding author's e-mail:

wolesuccess2000yahoo.com, adediran.adeolu@1mu.edu.ng (Adelou Adesoji Adediran) comprise strong load-carrying material (known as reinforcement) embedded in a weaker material (known as the matrix). For the manufacture of composites two materials must be provided: a) matrix materials, which can be either metallic, ceramic, or polymeric materials and b) reinforcing material. ${ }^{1}$ Reinforcement provides strength and rigidity, helping to support a structural load. ${ }^{2,3}$ The individual components remain separate and distinct within the finished structure. However, the properties of reinforced polymer composites can change owing to degradation of the selected materials used for the development of such composites. These changes usually have a negative effect on the performance of the materials in service with time. Reinforcements from natural sources are usually highly affected in this mode. 
Palm kernel shell is a waste product from palm kernel fruit after the extraction of the palm oil from the fruit. Palm kernel is a perennial crop that is readily available throughout the year. ${ }^{4}$ Research on the tensile and flexural properties of natural-fiber-reinforced vinyl ester composites has been done and evaluated. ${ }^{5}$ The mathematical models for tensile, flexural and impact properties were developed using statistical packages and optimization with the aid of the genetic algorithm method to find the optimum fiber parameters for a maximum value of the mechanical properties. ${ }^{6}$ A lot of work has been done using natural fibers as a reinforcement in polymer for composites' development, but not much has been done in studying the biodegradation characteristics of these composites. It is important to know the degradability of composites and to model such in the case of future applications. This will enable an accurate prediction of the composite's degradability before experimentation. Recently, ${ }^{7-9}$ reported on the improvement of properties of selected polymer composites. From their work, it was observed that the degradation rate of polymer-based composites improved significantly when natural fillers were used. This research is designed to primarily investigate the influence of palm-kernel-shell-ash-reinforced epoxy composites on polymer degradation. The alteration in properties of the composites, when subjected to different service environments, has given them low durability, functionality, and longevity in service. There have been limitations on the prediction of composite material properties over time, while in service in specific environs. As a result, more work needs to be done on modeling of particulate/fiber-reinforced polymer composites to improve the accurate prediction of composite material properties and reduce the experimentation in future applications.

\section{EXPERIMENTAL PART}

\subsection{Materials}

The burnt palm kernel shell used for this research was obtained from a local blacksmith in Akure, Ondo State, Nigeria, while the hardener and epoxy resin were obtained from Lagos State, Nigeria. The palm kernel shell ash contains some inclusions and some other unwanted materials, which were hand-picked from the palm kernel shell ash before pulverizing and ball milling. Sieving of the ball-milled palm kernel shell ash (PKSA) was carried out using a set of sieves to obtain $-150+106$ $\mu \mathrm{m}$ using a sieve shaker that operates at $1500 \mathrm{~min}^{-1}$ for $15 \mathrm{~min}$. The final particle size that was used for this research was $150 \mu \mathrm{m}$.

\subsection{Preparation of mold and samples production}

The tensile mold of gauge length $90 \mathrm{~mm} \times 10 \mathrm{~mm} \times$ $5 \mathrm{~mm}$ of a dumb-bell shape and flexural mold of $150 \mathrm{~mm}$ $\times 50 \mathrm{~mm} \times 5 \mathrm{~mm}$ were used for the production of tensile and flexural samples, respectively. Mold-release agent was applied on the surface of the aluminum mold to aid easy removal of the cured samples before pouring of the homogenous pastes. Palm-kernel-shell-ash-reinforced epoxy composites were produced at room temperature. The granulated palm kernel shell ash was mixed with the epoxide-hardener mixture and poured into the molds, as recommended by ${ }^{9,10}$. The molds used for the fabrication were for tensile and flexural (flexural) specifications. The basis of the mold used for each weight composition is $330 \mathrm{~g}$, which consisted of 3 tensile and flexural test samples. The manual mixing method and hand lay-up technique were used for the composite production. The composite samples were prepared using $(2,4,6,8,10$, $12,14,16,18$ and 20) $w / \%$ fractions of the palm kernel shell ash particles, as shown in the Table 1. The matrix material (epoxy resin and curing hardener) was prepared in the ratio of $4 \mathrm{~g}$ of epoxy resin to $1 \mathrm{~g}$ of the curing hardener (4:1), in accordance with. ${ }^{11}$ The palm kernel shell ash particles were first added to the epoxy resin and mixed thoroughly before adding the hardener. The mixture was stirred gently and thoroughly to ensure homogeneity, then it was poured into the prepared mold and allowed to cure. The composite samples were left at room temperature to cure for hours before removal, as reported by ${ }^{12}$. The different curing times were record, as shown in Table 1, where it was observed that the curing time reduced as the reinforcement content increased. This implied that the addition of the reinforcement could aid a rapid manufacturing rate for mass production.

Table 1: Composition used to produce the composite samples

\begin{tabular}{|c|c|c|c|c|c|}
\hline $\begin{array}{c}\text { Sample } \\
(w / \%)\end{array}$ & Epoxy $(\mathrm{g})$ & $\begin{array}{c}\text { Hardener } \\
(\mathrm{g})\end{array}$ & $\begin{array}{c}\text { Palm } \\
\text { kernel } \\
\text { shell ash } \\
(\mathrm{g})\end{array}$ & $\begin{array}{c}\text { Wt. of } \\
\text { composite } \\
(\mathrm{g})\end{array}$ & $\begin{array}{c}\text { Curing } \\
\text { time }(\mathrm{h}, \\
\text { min })\end{array}$ \\
\hline Control & 264.00 & 66.00 & - & 330 & 3 \\
\hline 2 & 258.72 & 64.68 & 6.6 & 330 & $2: 30$ \\
\hline 4 & 242.44 & 63.36 & 13.20 & 330 & $2: 30$ \\
\hline 6 & 248.16 & 62.04 & 19.8 & 330 & $2: 25$ \\
\hline 8 & 242.88 & 60.72 & 26.40 & 330 & $2: 25$ \\
\hline 10 & 237.60 & 59.40 & 33.00 & 330 & $2: 20$ \\
\hline 12 & 232.32 & 58.08 & 39.60 & 330 & $2: 20$ \\
\hline 14 & 227.04 & 56.76 & 46.20 & 330 & $2: 15$ \\
\hline 16 & 221.76 & 55.44 & 52.80 & 330 & $2: 10$ \\
\hline 18 & 216.48 & 54.12 & 59.40 & 330 & $2: 10$ \\
\hline 20 & 211.20 & 52.80 & 66.00 & 330 & 2 \\
\hline
\end{tabular}

\subsection{Testing of samples}

The developed samples were divided into three sets; this was done to be able to evaluate the degradation of the composites. The first set was tested after production and curing, the second and third sets were subjected to immersion in water and buried in the soil for 90 days prior to the tests. This was done to study and check for the degradation in the mechanical properties because of the different environment in which they were exposed. The tensile test was performed on flat samples with a 
dog-bone shape using an INSTRON 1195 at a fixed crosshead speed of $10 \mathrm{~mm} / \mathrm{min}$. Samples were prepared according to ASTM D412 13 for the determination of the tensile properties. To carry out the test, the grip for the test was fixed on the machine and the sample, which had been cut into the test piece dimension of $150 \mathrm{~mm} \times 50$ $\mathrm{mm} \times 5 \mathrm{~mm}$, was hooked on the grip and the test commenced. As the specimen was stretched, the computer generated the required data and graphs. The flexural test was carried out using the same Universal Testing Machine in accordance with ASTM D790. ${ }^{14}$ The flexural test was performed at a speed of $100 \mathrm{~mm} / \mathrm{min} .{ }^{15}$

\subsection{Characterization of samples}

The developed samples were prepared for X-ray diffractometry (XRD) analysis using a back-loading preparation method. The analysis was then carried out with a PANalytical Empyrean diffractometer having a PIXcel detector and fixed slits with Fe filtered $\mathrm{Cu}-K_{\alpha}$ radiation $(\lambda=0.00015406 \mathrm{~nm})$ at $2 \theta$ between $20^{\circ}$ to $80^{\circ}$. The phases were identified using $X$ 'Pert Highscore plus software, as reported by ${ }^{16}$. The morphological feature showing the cross-section of the composite was assessed using a Field-Emission Scanning Electron Microscope (JSM-7800F) operated at $20 \mathrm{kV}$.

\subsection{Modeling and validation}

The experimental results obtained were analyzed using statistical analyses and then used to develop and validate mathematical models using least-squares regression analyses with Microsoft Excel software. The Perron-Frobenius theorem was used during validation for the ranking of the regression parameters, including $R^{2}$, Standard Error, $F$ and Significant $F$, and pair t-test data in order to determine the model with the best fit. The Perron-Frobenius theorem tells us that there is always a solution to the popularity problem. The theory also tells us that uniqueness is usually true and explains the circumstances when it is not. This theorem was applied to specific regression parameters obtained upon analysis

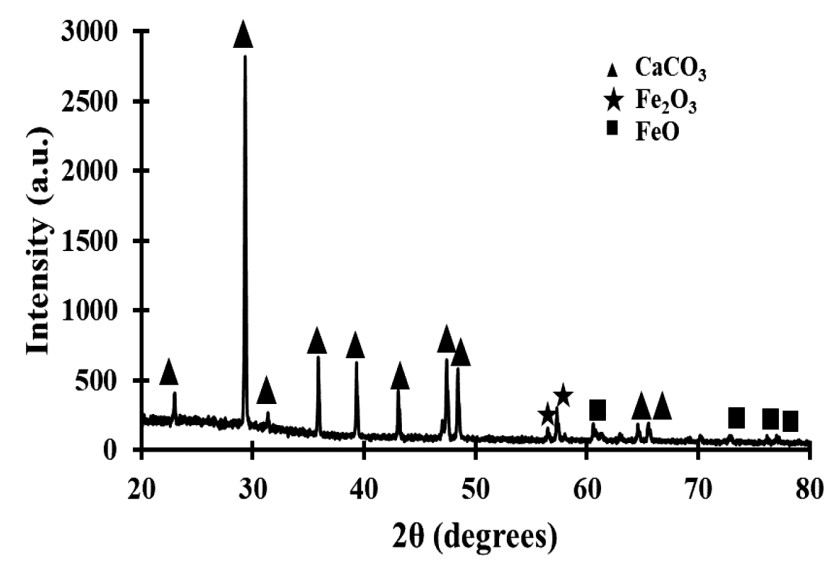

Figure 1: XRD profile of the palm kernel shell $\mathrm{ash}^{9}$ and modeling to determine which polynomial model was the best fit. The models were then used to generate data and charts, which were further analyzed to determine the validity of the models.

\section{RESULTS}

The XRD spectra showed the various phases in the sample, as presented in Figure 1.

A representative scanning electron microscopy (SEM) image showing the cross-section of the composite is as presented in Figure 2.

Table 2: Experimental and model flexural strength for the PKSA-reinforced epoxy composite sample

\begin{tabular}{|c|c|c|c|c|c|c|}
\hline \multirow{2}{*}{$\begin{array}{c}w / \% \\
\mathrm{x}\end{array}$} & \multicolumn{2}{|c|}{ Normal $(\mathrm{MPa})$} & \multicolumn{2}{c|}{ Soil (MPa) } & \multicolumn{2}{c|}{ Water $(\mathrm{MPa})$} \\
\cline { 2 - 7 } & $\begin{array}{c}\text { Experi- } \\
\text { mental }\end{array}$ & Model & $\begin{array}{c}\text { Experi- } \\
\text { mental }\end{array}$ & Model & $\begin{array}{c}\text { Experi- } \\
\text { mental }\end{array}$ & Model \\
\hline 0 & 3.58 & 3.89 & 27.49 & 26.87 & 27.88 & 27.81 \\
\hline 2 & 6.04 & 5.22 & 30.25 & 30.94 & 10.14 & 10.26 \\
\hline 4 & 7.80 & 7.99 & 31.29 & 34.86 & 6.95 & 7.33 \\
\hline 6 & 11.06 & 10.73 & 41.53 & 37.75 & 9.09 & 8.06 \\
\hline 8 & 7.46 & 12.73 & 51.36 & 39.09 & 6.81 & 7.68 \\
\hline 10 & 22.63 & 13.85 & 13.92 & 38.71 & 5.24 & 5.68 \\
\hline 12 & 11.96 & 14.31 & 49.61 & 36.78 & 4.05 & 3.89 \\
\hline 14 & 8.65 & 14.55 & 35.34 & 33.80 & 2.67 & 4.57 \\
\hline 16 & 21.29 & 15.03 & 30.20 & 30.63 & 8.54 & 8.48 \\
\hline 18 & 14.05 & 16.03 & 25.99 & 28.49 & 10.22 & 12.96 \\
\hline 20 & 18.17 & 17.52 & 30.06 & 28.92 & 7.57 & 10.01 \\
\hline
\end{tabular}

Table 3: Experimental and model flexural modulus for the PKSAreinforced epoxy composite samples

\begin{tabular}{|c|c|c|c|c|c|c|}
\hline \multirow{2}{*}{$\begin{array}{c}w / \% \\
\mathrm{x}\end{array}$} & \multicolumn{2}{|c|}{ Normal $(\mathrm{MPa})$} & \multicolumn{2}{c|}{ Soil $(\mathrm{MPa})$} & \multicolumn{2}{c|}{ Water $(\mathrm{MPa})$} \\
\cline { 2 - 7 } & $\begin{array}{c}\text { Experi- } \\
\text { mental }\end{array}$ & Model & $\begin{array}{c}\text { Experi- } \\
\text { mental }\end{array}$ & Model & $\begin{array}{c}\text { Experi- } \\
\text { mental }\end{array}$ & Model \\
\hline 0 & 28.20 & 24.35 & 750.35 & 726.36 & 66.67 & 83.90 \\
\hline 2 & 47.13 & 60.41 & 763.48 & 816.56 & 464.21 & 368.33 \\
\hline 4 & 64.00 & 52.69 & 816.22 & 870.98 & 218.77 & 395.71 \\
\hline 6 & 71.11 & 60.67 & 974.84 & 878.64 & 429.57 & 357.08 \\
\hline
\end{tabular}

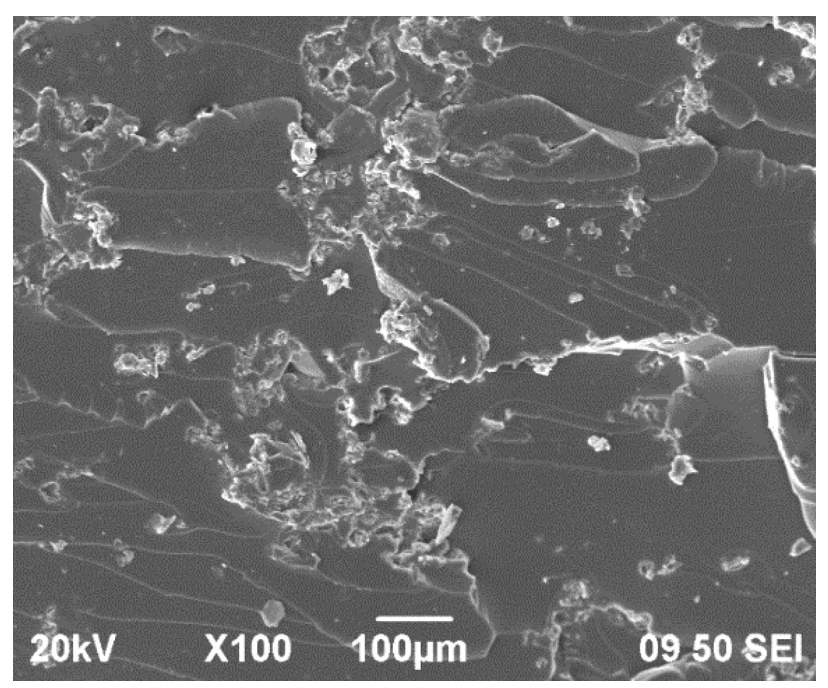

Figure 2: Secondary-electron image for $10 w / \%$ composite 
I. O. OLADELE et al.: MATHEMATICAL MODELS FOR EVALUATING THE INFLUENCE OF DEGRADATION ...

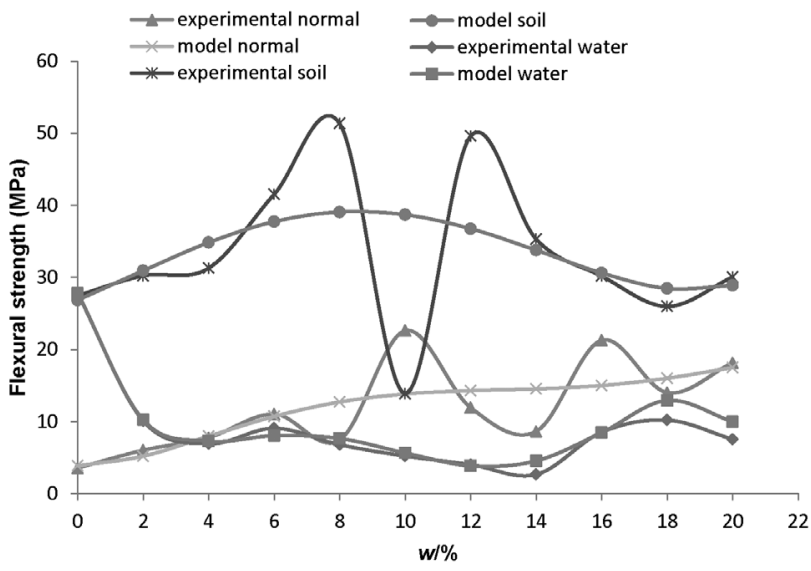

Figure 3: Flexural strength chart for the samples

\begin{tabular}{|c|c|c|c|c|c|c|}
\hline 8 & 57.21 & 91.95 & 1193.62 & 838.71 & 449.99 & 337.73 \\
\hline 10 & 165.29 & 126.07 & 112.31 & 760.47 & 307.76 & 349.90 \\
\hline 12 & 107.55 & 138.31 & 697.30 & 663.37 & 237.89 & 365.37 \\
\hline 14 & 59.57 & 123.46 & 1106.04 & 576.97 & 338.00 & 348.16 \\
\hline 16 & 151.11 & 119.71 & 255.92 & 540.99 & 447.15 & 287.10 \\
\hline 18 & 106.01 & 232.39 & 570.18 & 605.28 & 46.44 & 228.53 \\
\hline 20 & 533.11 & 657.79 & 871.04 & 829.82 & 276.63 & 308.90 \\
\hline
\end{tabular}

Table 4: Experimental and model tensile strength for the PKSA-reinforced epoxy composite sample

\begin{tabular}{|c|c|c|c|c|c|c|}
\hline \multirow{2}{*}{$\begin{array}{c}w / \% \\
\mathrm{x}\end{array}$} & \multicolumn{2}{|c|}{ Normal $(\mathrm{MPa})$} & \multicolumn{2}{|c|}{ Soil $(\mathrm{MPa})$} & \multicolumn{2}{c|}{ Water $(\mathrm{MPa})$} \\
\cline { 2 - 7 } & $\begin{array}{c}\text { Experi- } \\
\text { mental }\end{array}$ & Model & $\begin{array}{l}\text { Experi- } \\
\text { mental }\end{array}$ & Model & $\begin{array}{l}\text { Experi- } \\
\text { mental }\end{array}$ & Model \\
\hline 0 & 3.35 & 3.62 & 6.41 & 7.53 & 16.10 & 15.04 \\
\hline 2 & 7.97 & 7.08 & 7.61 & 4.45 & 7.96 & 11.29 \\
\hline 4 & 8.86 & 9.37 & 2.22 & 4.18 & 12.06 & 9.56 \\
\hline 6 & 9.87 & 10.58 & 3.56 & 5.25 & 10.08 & 9.13 \\
\hline 8 & 10.35 & 10.90 & 9.63 & 6.63 & 9.45 & 9.40 \\
\hline 10 & 12.84 & 10.55 & 3.14 & 7.69 & 7.56 & 9.88 \\
\hline 12 & 9.28 & 9.89 & 11.03 & 8.24 & 13.10 & 10.20 \\
\hline 14 & 7.29 & 9.30 & 6.82 & 8.50 & 8.68 & 10.12 \\
\hline 16 & 9.38 & 9.26 & 6.73 & 9.12 & 14.15 & 9.49 \\
\hline 18 & 10.24 & 10.34 & 6.43 & 11.17 & 9.46 & 8.29 \\
\hline 20 & 11.81 & 13.17 & 11.15 & 16.14 & 11.02 & 6.60 \\
\hline
\end{tabular}

Table 5: Experimental and model tensile modulus for the PKSA-reinforced epoxy composite samples

\begin{tabular}{|c|c|c|c|c|c|c|}
\hline \multirow{2}{*}{$\begin{array}{c}w / \% \\
\mathrm{x}\end{array}$} & \multicolumn{2}{|c|}{ Normal $(\mathrm{MPa})$} & \multicolumn{2}{|c|}{ Soil $(\mathrm{MPa})$} & \multicolumn{2}{c|}{ Water $(\mathrm{MPa})$} \\
\cline { 2 - 8 } & $\begin{array}{c}\text { Experi- } \\
\text { mental }\end{array}$ & Model & $\begin{array}{l}\text { Experi- } \\
\text { mental }\end{array}$ & Model & $\begin{array}{l}\text { Experi- } \\
\text { mental }\end{array}$ & Model \\
\hline 0 & 5.79 & 84.47 & 569.50 & 568.57 & 1356.57 & 1275.80 \\
\hline 2 & 693.48 & 413.47 & 430.73 & 339.00 & 588.17 & 875.65 \\
\hline 4 & 10.29 & 273.32 & 7.21 & 246.78 & 1152.30 & 810.52 \\
\hline 6 & 32.30 & 82.54 & 248.04 & 236.47 & 767.92 & 911.71 \\
\hline 8 & 22.77 & 13.37 & 670.47 & 267.17 & 1106.88 & 1053.93 \\
\hline 10 & 330.29 & 69.67 & 11.57 & 312.47 & 1036.75 & 1155.40 \\
\hline 12 & 73.72 & 164.94 & 430.48 & 360.50 & 1347.90 & 1177.80 \\
\hline 14 & 29.96 & 200.21 & 277.36 & 413.90 & 926.21 & 1126.27 \\
\hline 16 & 69.39 & 142.05 & 568.39 & 489.82 & 1191.82 & 1049.43 \\
\hline 18 & 143.59 & 100.46 & 686.22 & 619.91 & 1009.16 & 1039.35 \\
\hline 20 & 209.05 & 406.87 & 811.13 & 850.37 & 1230.13 & 1231.60 \\
\hline
\end{tabular}

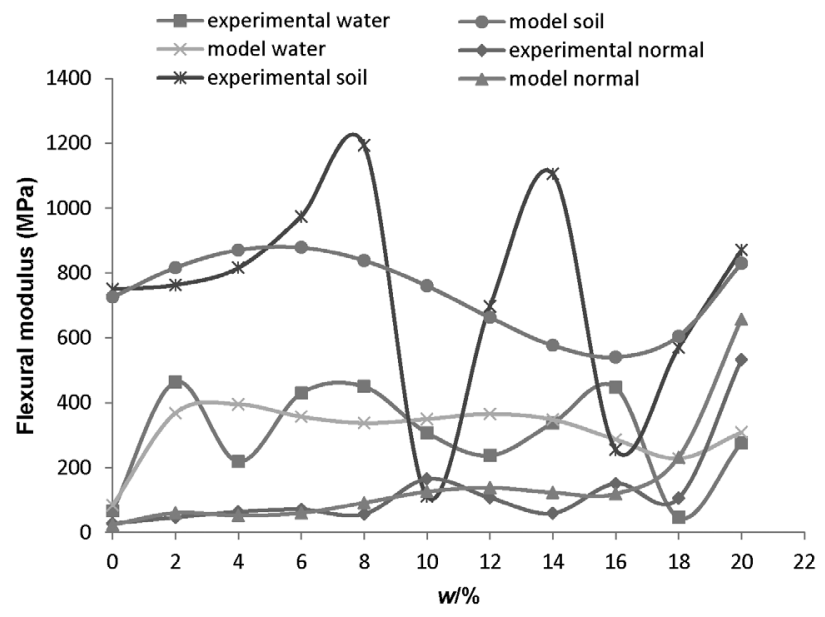

Figure 4: Flexural modulus chart for the samples

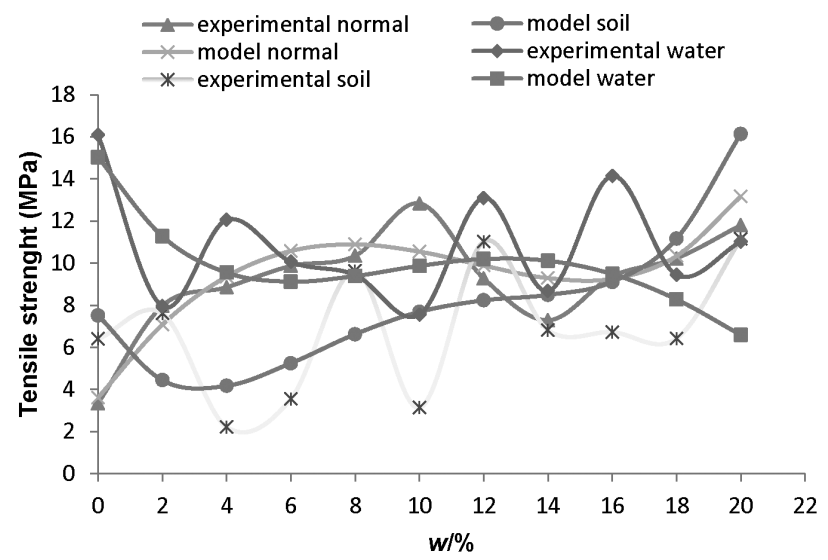

Figure 5: Tensile strength chart for the samples

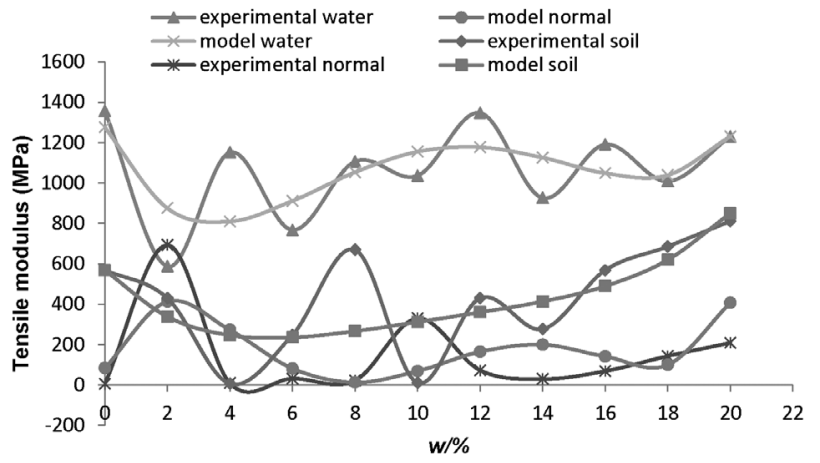

Figure 6: Tensile modulus chart for the samples

\section{DISCUSSION}

The XRD spectra presented in Figure 1 showed the various phases in the sample. At a $2 \theta$ value of about $56^{\circ}$, $\mathrm{Fe}_{2} \mathrm{O}_{3}$ was observed. The peaks associated with $\mathrm{CaCO}_{3}$ were observed to dominate the spectra at $2 \theta$ values of $24^{\circ}, 32^{\circ}, 36^{\circ}, 39-48^{\circ}$. The peaks belonging to $\mathrm{FeO}$ were noted at $2 \theta$ values of $62^{\circ}, 75-78^{\circ}$. Figure 1 revealed the XRD analysis of the particles, where it was observed that $\mathrm{CaCO}_{3}$ was the main constituent. 
Figure 2 shows the morphological features of the composite obtained (at $10 \mathrm{w} / \%$ composite) with a scanning electron microscope. From the image, a good dispersion of the PKSA in the epoxy matrix was observed. The interfacial adhesion between the PKSA and the epoxy matrix would have contributed to the enhancement in the mechanical properties when compared with the control sample.

Table 2 contains a compilation of the flexural strength results for the samples obtained after carrying out the test. It also contains the developed flexural strength model values of the samples. These model values were obtained through the use of Equations (1-3) (normal, soil, water), which are the developed models for the prediction of the flexural strength of the PKSA-reinforced epoxy composite samples.

$$
\begin{gathered}
y=-0.0047 x^{5}+0.2875 x_{4}-6.0127 x^{3}+46.4844 x^{2}- \\
+4.4661 x+388.8388 \\
y=0.000 x^{4}-0.028 x^{3}+0.128 x^{2}+1.886 x+26.86 \\
y=-0.000 x^{5}+0.026 x^{4}-0.491 x^{3}+4.104 x^{2}- \\
-15.21 x+27.80
\end{gathered}
$$

Similarly, Table 3 shows the result of the flexural modulus for samples obtained after carrying out the mechanical test. Equations (4-6) were used to determine these model values, each equation representing normal, soil and water, respectively, which are the developed models for the prediction of the flexural modulus of the PKSA-reinforced epoxy composite samples.

$$
\begin{gathered}
y=0.006 x^{5}+0.259 x^{4}-3.728 x^{3}+21.33 x^{2}- \\
+47.75 x+24.35 \\
y=0.026 x^{4}-0.545 x^{3}-1.938 x^{2}+50.94 x+726.3 \\
y=0.008 x^{5}-0.445 x^{4}+8.473 x^{3}-71.52 x^{2}+ \\
+254.7 x+83.89
\end{gathered}
$$

These are the flexural strength/modulus equations that depend on the weight fraction of the reinforcement of the composite samples. This means that the dependent variable of the model is the weight fraction. Polynomial equations of order 3, 4 and 5 where developed using the experimental values through the use of least-squares regression analyses with Microsoft Excel. And upon validation using Perron-Frobenius theorem, including $R^{2}$, Standard Error, $F$ and Significant $F$, and pair t-test data, order 5, 4 and 5 (normal, soil, water), respectively, were picked as the models for the prediction of the flexural strength/modulus of the samples. Order 5 was picked for the normal samples because it has values for $R^{2}, R_{\mathrm{m}}{ }_{\mathrm{m}}=$ $(0.7239,0.9324)$, which shows it has a very high positive correlation, ${ }^{17-19}$ while the $S . E_{s}, S . E_{m}=(0.0004,52.0525)$; which is a good result since the result is less than two digits in congruence with the samples size and based on this it is acceptable. ${ }^{20}$ The $F_{s}, F_{m}=(1.1014,13.7956)$ and S.F, S.F $F_{m}=(0.4591,0.0060)$ show the high significance of the model to the experimental data. Order 4 was picked for the soil samples because it has values for $R^{2}$,
$R_{\mathrm{m}}^{2}=(0.1658,0.1420)$, which shows it has a very high positive correlation ${ }^{18,19}$ while the $S . E_{s}, S . E_{m}=(12.6999$, 430.0009), a trend previously reported by ${ }^{20}$. The $F_{s}, F_{m}=$ $(0.2982,0.1654)$ and $S . F_{s}, S . F_{m}=(0.8692,0.9648)$. Order 5 was chosen for the water samples having values of $R_{\mathrm{s}}^{2}, R_{\mathrm{m}}{ }_{\mathrm{m}}=(0.9865,0.4066)$, which shows it has a very high positive correlation ${ }^{18,19}$. Also, the $\mathrm{S} . \mathrm{E}_{\mathrm{s}}, \mathrm{S} . \mathrm{E}_{\mathrm{m}}=$ (1.0992, 161.2636), indicating a good result, since it shows less than two digits in congruence with the sample sizes. ${ }^{20}$ The $F_{\mathrm{s}}, \mathrm{F}_{\mathrm{m}}=(73.3167,0.6852)$ and $\mathrm{S} . \mathrm{F}_{\mathrm{s}}, \mathrm{S} . \mathrm{F}_{\mathrm{m}}=$ $(0.0001,0.6558)$ show the high significance of the model when compared with the experimental data. This is because it has a confidence level above $95 \%$, since the "Significance $F$ " value is $<0.05$.

$R^{2}{ }_{\mathrm{s}}=$ Regression squares for strength property.

$R_{\mathrm{m}}^{2}=$ Regression squares for modulus.

$\mathrm{S} . \mathrm{E}_{\mathrm{s}}=$ Standard Error for strength property.

S. $E_{\mathrm{m}}=$ Standard Error for modulus.

$\mathrm{F}_{\mathrm{s}}, \mathrm{F}_{\mathrm{m}}=\mathrm{F}$ for strength and modulus, respectively.

S.F, S. $F_{m}=$ Significant $F$ for strength and modulus, respectively.

From Figure 2, the developed flexural strength models (using experimental and model data) for the water samples that follow suit with the experimental, without much dispersion or discrepancy, which was demonstrated in the models for normal and soil samples. This implied that the flexural strength model for the water samples, which is of order 5 , is the most dependable model for the flexural strength prediction when there is a higher weight fraction.

Figure 3 shows the developed flexural modulus models for the normal samples best follow suit with the experimental without much variation or dispersion, as indicated in the models for water and soil samples. This suggests that the FYM model for normal that is of order 5 is the most reliable model for flexural modulus prediction at higher percentage weight reinforcement followed by the water samples and lastly that of the soil samples in increasing order of discrepancy from the experimental data. As indicated in Figure 3, the developed FYM model for water samples is of order 5. It was manageably dependable at lower weight percentage of reinforcement from $2 w / \%$ to $6 w / \%$, while the developed FYM model for the soil samples, which is of order 4, is only manageably dependable at lower weight percentage reinforcement from $2 w / \%$ to $6 w / \%$.

The compilation of the tensile strength result is as presented in Table 4. The results show that model values were obtained through the use of Equations (7-9) (normal, soil, water), respectively. Indicating the developed models for the prediction of the tensile strength of the PKSA-reinforced epoxy composite samples.

$$
\begin{aligned}
& y=0.000 x^{4}-0.000 x^{3}-0.149 x^{2}+2.029 x+3.619 \\
& y=0.001 x^{4}-0.043 x^{3}+0.582 x^{2}-2.537 x+7.525 \\
& y=0.000 x^{4}-0.018 x^{3}+0.354 x^{2}-2.509 x+15.03
\end{aligned}
$$


Representative tensile modulus result of the samples obtained after a mechanical test is as presented in Table 5. It shows the variation in the developed tensile modulus model values of the samples. These values were generated using Equations (10-12) (normal, soil, water), respectively, which are the developed models for the prediction of the tensile modulus of the PKSA-reinforced epoxy composite samples.

$$
\begin{gathered}
\begin{array}{r}
y=0.0203 x^{5}-1.0474 x^{4}-19.2583 x^{3}+147.3 x^{2}+ \\
+
\end{array}+390.12 x+84.472 \\
\begin{array}{r}
y=0.0378 x^{4}-1.6083 x^{3}+25.759 x^{2}-160.17 x+ \\
\quad+568.57
\end{array} \\
y=0.113 x^{4}-4.873 x^{3}+67.95 x^{2}-317.3 x+1275
\end{gathered}
$$

These are tensile strength/modulus equations that depend on the weight fraction of the reinforcement of the composite samples. This means that the dependent variable of the model is the weight fraction. Polynomial equations of order 3,4 and 5 were developed using the experimental values through the use of least-squares regression analyses with Microsoft Excel. Upon validation using the Perron-Frobenius theorem including R2, Standard Error, F and Significant F, and pair t-test data, order $(4,5), 4$ and 5 (normal, soil, water), respectively, were picked as the models for the prediction of tensile strength/modulus of the samples. Order $(4,5)$, respectively, was picked for the normal samples because it has values for $\mathrm{R}_{\mathrm{s}}{ }, \mathrm{R}_{\mathrm{m}}{ }_{\mathrm{m}}=(0.8166,0.3597)$, which shows it has a very high positive correlation ${ }^{18,19}$, while the $\mathrm{S} \mathrm{E}_{\mathrm{s}}$, S.E $E_{m}=(1.3815,234.2217)$; which is a good result since the result is less than two digits in congruence with samples size and based on this it is acceptable. ${ }^{20}$ The $\mathrm{F}_{\mathrm{s}}$, $F_{m}=(6.6803,0.5618)$ and $S . F_{s}, S . F_{m}=(0.0213,0.7289)$ shows the high significance of the model to the experimental data. Order 4 was chosen for the soil samples because it has values for $\mathrm{R}_{\mathrm{s}}{ }_{\mathrm{s}}, \mathrm{R}_{\mathrm{m}}{ }_{\mathrm{m}}=(0.3460,0.5056)$, which shows it has a very high positive correlation ${ }^{18,19}$ while the $S . E_{s}, S . E_{m}=(3.1430,254.3302)$; which is a good result since the result is less than two digits in congruence with the samples size and based on this it is acceptable. ${ }^{20}$ The $F_{s}, F_{m}=(0.7935,1.2187)$ and S.F , $\mathrm{S} . \mathrm{F}_{\mathrm{m}}=(0.5701,0.4167)$. Order 5 was picked for the water samples because it has values for $\mathrm{R}_{\mathrm{s}}{ }_{\mathrm{r}}, \mathrm{R}_{\mathrm{m}}{ }_{\mathrm{m}}=$ $(0.3371,0.4005)$, which shows it has a very high positive correlation while the $S . E_{s}, S . E_{m}=(2.8476,235.8195)$; which is a good result since the result is less than two digits in congruence with the samples size and based on this it is acceptable. The $F_{s}, F_{m}=(0.7628,1.0021)$ and S.F, S.F $F_{m}=(0.5859,0.4743)$ shows the high significance of the model with respect to the experimental data.

The developed tensile strength (TS) model of the normal samples when compared with the experimental had a discrepancy from $2 w / \%$ to $8 w / \%$. This was demonstrated in the models for the water and soil samples, respectively. It implies that the tensile strength model for normal, which is of order 4, is manageably dependable for an ultimate tensile strength prediction at higher percentage weight fraction. Also, the water samples increase in the order of discrepancy from the experimental data.

The developed tensile modulus (TM) model for the soil samples follows the same trend as the experimental without much discrepancy. Specifically, at higher percentage weight reinforcement from $12 \mathrm{w} / \%$ to $20 \mathrm{w} / \%$ when compared with that of normal and water samples. This indicates that the TM model for soil samples, which is of order 4, is most dependable for a TYM prediction at a higher percentage weight reinforcement from $12 \mathrm{w} / \%$ upward. The next model of moderate disparity between 8 $w / \%$ and $20 w / \%$ that follows the one for soil samples is that of water samples, which is of order 4 . It is manageably dependable for the TYM prediction for a higher weight percentage reinforcement from $8 \mathrm{w} / \%$ upwards.

\section{CONCLUSIONS}

Instead of carrying out some experimental research to determine the strength level of a PKSA-reinforced epoxy composite when used in an open atmosphere, water or soil, the developed models can be used to predict the strength level after 90 days, depending on the accuracy level the user desires.

\section{Acknowledgment}

Authors appreciate the Federal University of Technology Akure and Landmark University, Omu-Aran for their support.

\section{REFERENCES}

${ }^{1}$ A. I. Al-Mosawi, S. A. Abdulsada, M. A. Muslim, Analysis Modeling for estimation tensile and flexural strength of green composite, Advances in Chemistry and Materials Science, 2 (2016) $1,1-7$

${ }^{2}$ U. J. Alengaram, H. Mahmud, M. Z. Jumaat, Enhancement and prediction of modulus of elasticity of palm kernel shell concrete, Materials and Design Journal, 32 (2010) 4, 2143-2148, doi:10.1016/ j.matdes.2010.11.035

${ }^{3}$ H. Larbig, H. Scherzer, B. Dahlke, R. Poltrock, Natural fibre reinforced foams based on renewable resources for automotive interior application, Journal of Cellular Plastics, 34 (1998) 4, 361-379, doi:10.1177/0021955X9803400406

${ }^{4}$ M. Afolabi, O. K. Abubakre, A. R. Lawal, Experimental investigation of palm kernel shell and cow bone reinforced polymer composites for brake pad production, International Journal of Chemistry and Materials Contribution, 3 (2015) 2, 27-40

${ }^{5}$ S. Velumani, K. P. Navaneetha, S. Jayabal, Mathematical odeling and optimization of mechanical properties of short coir fiber-reinforced vinyl ester composite using genetic algorithm method, Mechanics of Advanced Materials and Structures, 21 (2014), 559-565, doi:10.1080/15376494.2012.699599

${ }^{6}$ I. O. ladele, N. I. Agbeboh, Development of mathematical models and estimation for the mechanical properties of organic fiber reinforced polyester composites, Fibers and Polymers, 18 (2017) 7, 1336-1345, doi:10.1007/s12221-017-1064-2

${ }^{7}$ S. T. Sam, H. Ismail, Z. Ahmad, Soil burial of polyethyleneg-(maieic anhydride) compatibilised LLDPE/soya powder blends, 
Polym. - Plast. Technol. Eng., 50 (2011), 851-861, doi:10.1080/ 03602559.2011.551977

${ }^{8}$ A. L. Pang, H. Ismail, A. Abu Bakar, Degradation of linear low density polyethylene/poly(vinyl alcohol)/kenaf composites, Iran Polym. J., 26 (2017), 703-709, doi:10.1007/s13726-017-0555-8

${ }^{9}$ I. O. Oladele, A. D. Akinwekomi, O. G. Agbabiaka, M. O. Oladejo, Influence of biodegradation on the tensile and wear resistance properties of bio-derived $\mathrm{CaCO}_{3}$ /epoxy composites, Journal of Polymer Research, 26 (2019) 16, doi:10.1007/s10965-018-1676-2

${ }^{10}$ I. O. Oladele, O. A. Adewumi, O. R. Bello, Wear and thermal properties of hybrid palm kernel fruit reinforced polyester composites, Annals of the Faculty of Engineering Hunedoara, 13 (2015) 4, 69-74

${ }^{11}$ F. Asuke, V. S. Aigbodion, Experiment numerical study of dry sliding wear behaviour of epoxy/periwinkles shell particulate composites, Journal of the Chinese Advanced Materials Society, 4 (2016) 2, 123-139, doi:10.1080/22243682.2015.1124736

${ }^{12}$ I. O. Oladele, J. L. Olajide, M. Amujede, Wear resistance and mechanical behaviour of epoxy/mollusk shell biocomposites developed for structural applications, Tribology in Industry, 38 (2016) 3, 347-360

${ }^{13}$ ASTM D412-16: Standard Test Methods for Vulcanized Rubber and Thermoplastic Elastomers-Tension, ASTM International, West Conshohocken, PA, 2016
${ }^{14}$ ASTM D7264/D7264M-15: Standard test method for flexural properties of polymer matrix composite materials, ASTM International, West Conshohocken, PA, 2015

${ }^{15}$ ASTM D790: Standard test methods for flexural properties of unreinforced and reinforced plastics and electrical insulating materials, ASTM International, West Conshohocken, PA, 2002

${ }^{16}$ A. A. Adediran, K. K. Alaneme, I. O. Oladele, E. T. Akinlabi, Processing and structural characterization, Cogent Engineering, 5 (2018) 1-12, doi:10.1080/23311916.2018.1494499

${ }^{17}$ J. O. Agunsoye, S. I. Talabi, V. S. Aigbodion, A. Olumuyiwa, Effects of silica ceramic particle sizes on the properties of recycled polyethylene composites, Advances in Natural Science, 6 (2013) 1, 1-8

${ }^{18}$ E. Okoro, Quantitative techniques in urban analysis, Krast Books Limited: Ibadan Nigeria, 2000, 17-185

${ }^{19}$ A. Oyetunji, J. A. Adebisi, Development of software for rapid estimation of corrosion rate of austempered ductile iron in corrosive media, Australian Journal of Basic and Applied Sciences, ISI Net Publication, 3 (2009) 3, 2801-2808

${ }^{20}$ J. Kusiak, R. Kuziak, Modelling of microstructure and mechanical properties of steel using the artificial neutral network, Journal of Materials Processing Technologie, 127 (2002) 1, 115-121, doi:10.1016/S0924-0136(02)00278-9 